\title{
Treading lightly as we step into a new era: Use of hepatitis C virus-infected organs for transplantation
}

\author{
Yasbanoo Moayedi, MD, ${ }^{\text {a,b }}$ Aliya F. Gulamhusein, MD, MPH, ${ }^{c}$ and Kiran K. Khush, MD, MAS ${ }^{b}$
}

\footnotetext{
From the ${ }^{\mathrm{a}}$ Ted Rogers Centre of Excellence in Heart Function, Peter Munk Cardiac Centre, and ${ }^{\mathrm{c}}$ Toronto Centre for Liver Disease, University Health Network, Toronto, Ontario, Canada; and ${ }^{\mathrm{b}}$ Section of Heart Failure, Cardiac Transplant, and Mechanical Circulatory Support, Division of Cardiovascular Medicine, Department of Medicine, Stanford University, Stanford, Calif.

Received for publication May 13, 2019; revisions received May 13, 2019; accepted for publication May 18, 2019; available ahead of print Oct 3, 2019.

Address for reprints: Kiran K. Khush, MD, MAS, Section of Heart Failure, Cardiac Transplant, and Mechanical Circulatory Support, Division of Cardiovascular Medicine, Department of Medicine, Stanford University, 300 Pasteur Dr, Falk Research Building, Stanford, CA 94305 (E-mail: kiran@stanford.edu).

J Thorac Cardiovasc Surg 2020;159:505-10

$0022-5223 / \$ 36.00$

Copyright (C) 2019 by The American Association for Thoracic Surgery

https://doi.org/10.1016/j.jtcvs.2019.05.091
}

An unprecedented number of heart transplants were performed in the United States during $2016,{ }^{1}$ yet $15 \%$ of patients on the waitlist either died or became too sick for transplant. ${ }^{2}$ Wait times remain unacceptably high for heart transplant candidates. As a result, there has been growing interest in the development of innovative strategies to mitigate the donor organ shortage. During the past decade, the opioid epidemic in the United States has led to a dramatic increase in the number of organ donors who died as a result of drug intoxication. ${ }^{3}$ Closely associated with this rise, hepatitis $\mathrm{C}$ virus (HCV) infection increased by $400 \%$ among 18- to 29 -year olds and $325 \%$ in 30 - to 39 -year olds during the same time period. ${ }^{4}$ Historically, many of these HCVviremic (herein referred to as $\mathrm{HCV}$-infected) donor organs would be discarded due to anticipated poor recipient shortand long-term survival after transplantation. However, mechanistic insights into the replication of $\mathrm{HCV}$ have enabled the development of highly effective and well tolerated direct acting antivirals (DAA) for HCV treatment. ${ }^{5}$ This article provides an overview of the management of HCV-infected donor organs, highlighting important considerations in the setting of thoracic transplantation. We discuss the current status of using HCV-infected organs for transplantation, the remaining long-term uncertainties of this approach, and novel strategies for using HCVinfected organs.

Currently, a minority of HCV-infected organs are accepted for thoracic transplantation. Based on a United Network Organ Sharing registry analysis, only 64 of $1078 \mathrm{HCV}$-infected donor hearts were accepted for transplantation from 2014 to $2017 .^{6}$ These donors had otherwise favorable characteristics: they were young with a median age of 32 years (interquartile range [IQR], 2737 years) and had significantly fewer comorbidities such as diabetes and hypertension when compared with the general donor population. ${ }^{6,7}$ Based on this registry analysis, more than 800 donor hearts were discarded

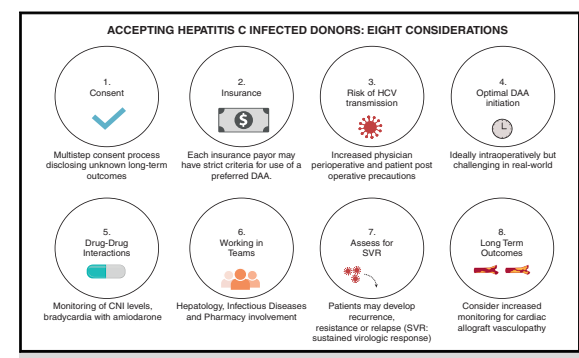

Important considerations in accepting HCV-infected donor organs.

Central Message

Important considerations in accepting $\mathrm{HCV}$ infected donor organs include consent, insurance coverage, universal precautions, optimal drug timing, drug interactions, therapy failure, and long-term safety.

This Invited Expert Opinion provides a perspective on the following paper: $N$ Engl $J$ Med. 2019;380:1606-1617. https://doi.org/10. 1056/NEJMoa1812406.

See Commentary on page 511.

due to $\mathrm{HCV}$ infection, which may represent a valuable missed opportunity for critically ill candidates on the waitlist. Many transplant centers, those particularly in United Network Organ Sharing regions 3, 4, 7, 8, 9, and 10 have been very cautious about accepting HCV-infected organs (Figure 1).

The treatment of chronic HCV infection has evolved from the highly toxic and poorly tolerated interferon- and ribavirin-containing regimens to the new landscape of DAA agents. ${ }^{8}$ There are currently 4 classes of DAAs, each targeting a unique nonstructural viral protein: NS3/NS4A protease inhibitors, inhibitors of the NS5A complex, and inhibitors of the NS5B polymerase that are subdivided into nucleos $(\mathrm{t})$ ide inhibitors and nonnucleos $(\mathrm{t})$ ide inhibitors and differ in individual potency and barriers to resistance. ${ }^{8,9}$ In 2014, the Food and Drug Association approved the first interferon and ribavirin-free regimen consisting of a once-daily combination pill (sofosbuvir/ ledipasvir). ${ }^{8}$ Early studies in the transplant setting established the efficacy of DAAs among donor negative (D-)/recipient positive $(\mathrm{R}+)$ mismatch patients with $>95 \%$ efficacy. Charlton and colleagues ${ }^{10}$ were among the first to treat $111 \mathrm{HCV}$-infected (99\% genotype 1) liver 


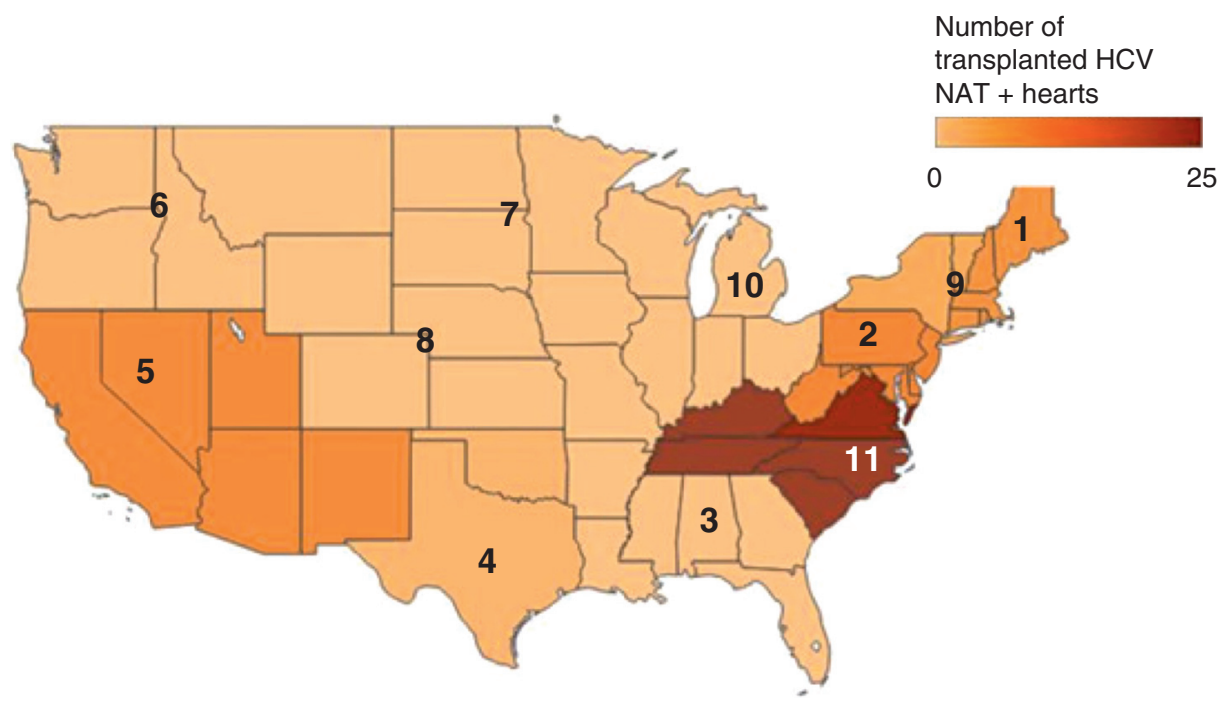

FIGURE 1. Number of hepatitis C NAT + heart donors transplanted by United Network Organ Sharing region from 2014 to 2017. NAT, Nucleic acid amplification test. Modified with permission (license No. 4594090471746) from Moayedi and colleagues. ${ }^{6}$

transplant recipients with a 12- and 24-week course of ledispavir/sofosbuvir and ribavirin, achieving sustained virologic response (SVR) in 96\% and 98\%, respectively. Similarly, 114 kidney transplant patients who were more than 6 months beyond transplantation achieved SVR of $100 \%$ using a combination of ledipasvir/sofosbuvir. ${ }^{11}$ Twelve Taiwanese heart transplant recipients were treated with sofosbuvir combined with ledipasvir or daclastavir. These patients all tolerated treatment for chronic HCV without interruption or adverse events, achieving SVR in $100 \%$ of cases. $^{12}$ Table 1 describes DAAs currently available for the treatment of $\mathrm{HCV}$.

\section{UTILIZATION OF HCV-INFECTED ORGANS IN TRANSPLANT SETTINGS}

Treatment of acute HCV in an immunocompromised host differs from treatment of immune-competent individuals with chronic HCV. In the April 25, 2019, issue of The New England Journal of Medicine, Woolley and colleagues ${ }^{13}$ published the results of the open-label pilot and efficacy Donors of Hepatitis C Nucleic Acid Amplification Test-Positive Thoracic Allografts for Transplantation Evaluation in non-HCV Recipients study. This study included 44 adults (36 lung and 8 heart transplant recipients) who received $\mathrm{HCV}$-infected organs. Recipients were preemptively treated with sofosbuvir $(400 \mathrm{mg}) / \mathrm{velpatasvir}(100 \mathrm{mg})$ within hours of transplantation for a total of 4 weeks. Of 35 patients with 6-months' follow-up, all had normal allograft function with undetectable viral load within 2 weeks of transplantation. That work builds on previous published studies evaluating the utilization of HCV-infected donor hearts for uninfected recipients. Schlendorf and colleagues ${ }^{14}$ reported the results of early outcomes of permissive HCV viral transmission in

TABLE 1. Direct-acting antiviral (DAA) drugs used in transplant settings ${ }^{8}$

\begin{tabular}{|c|c|c|c|}
\hline DAA & Drug name & Genotype coverage & Notes \\
\hline Sofosbuvir/ledipasvir & Harvoni (Gilead Sciences, Foster City, Calif) & 1,4 & $\begin{array}{l}\text { No data on calcineurin inhibitor interaction } \\
\text { (no a priori adjustment recommended) }\end{array}$ \\
\hline Sofosbuvir/velpatasvir & Epclusa (Gilead Sciences) & $1,2,3,4,5,6$ & No data on tacrolimus interaction \\
\hline Glecaprevir/pibrentasvir & Mavyret (AbbVie, North Chicago, Ill) & $1,2,3,4,5,6$ & $\begin{array}{l}45 \% \text { increase in tacrolimus levels, no a priori } \\
\text { dose adjustment recommended, drug level } \\
\text { monitoring is advised } \\
\text { Can be used in hemodialysis and chronic } \\
\text { kidney disease }\end{array}$ \\
\hline Elbasvir/graszoprevir & Zepatier (Merck, Kenilworth, NJ) & 1,4 & $\begin{array}{l}43 \% \text { increase in tacrolimus levels; no a priori } \\
\text { drug dose adjustment recommended } \\
\text { Can be used in hemodialysis and chronic } \\
\text { kidney disease }\end{array}$ \\
\hline Sofosbuvir/daclatasvir & $\begin{array}{l}\text { Daklinza (Bristol-Myers Squibb, } \\
\text { New York, NY). }\end{array}$ & $1,2,3,4$ & $\begin{array}{l}\text { No effect on tacrolimus levels, no a priori } \\
\text { adjustment needed }\end{array}$ \\
\hline
\end{tabular}

DAA, Direct-acting antiviral. 
TABLE 2. Contemporary studies on the utilization of hepatitis C virus (HCV)-infected donors in adult thoracic transplantation

\begin{tabular}{|c|c|c|c|c|c|}
\hline Author, Institution (Date) & Study (N) & $\begin{array}{l}\text { Recipients } \\
\text { included }\end{array}$ & $\begin{array}{c}\text { Donor HCV } \\
\text { exposure }\end{array}$ & DAA & Results \\
\hline $\begin{array}{l}\text { Woolley and colleagues, }{ }^{13} \\
\text { Brigham, Boston, Mass } \\
\text { (2019) }\end{array}$ & $\begin{array}{l}\text { Pilot study } \\
\qquad(\mathrm{N}=44)\end{array}$ & $\begin{array}{l}\text { Heart }(\mathrm{n}=8) \\
\text { Lung }(\mathrm{n}=36)\end{array}$ & $\mathrm{NAT}+$ & $\begin{array}{l}\text { Sofosbuvir/ } \\
\quad \text { velpatasvir } \times 4 \mathrm{wk}\end{array}$ & $\begin{array}{l}\text { SVR achieved in } 100 \% \text { by } \\
2 \text { wk; } \\
\text { Excellent 6-mo survival }\end{array}$ \\
\hline $\begin{array}{l}\text { Schlendorf and colleagues, }{ }^{15} \\
\text { Vanderbilt, Nashville, Tenn } \\
\text { (2019) }\end{array}$ & $\begin{array}{l}\text { Case series } \\
\qquad(\mathrm{N}=74)\end{array}$ & Heart & $\begin{array}{l}\text { NAT }+ \text { or } \\
\text { HCV Ab+ }\end{array}$ & $\begin{array}{l}\text { Sofosbuvir/ledipasvir } \\
\text { Sofosbuvir/velpatasvir } \\
\text { Glecaprevir/pibrenstasvir }\end{array}$ & $\begin{array}{l}\text { 30-d survival } 95 \% ; 1-y \\
\text { survival } 90.2 \%\end{array}$ \\
\hline $\begin{array}{l}\text { Aslam and colleagues, }{ }^{16} \\
\text { UCSD, San Diego, Calif } \\
\text { (2019) }\end{array}$ & $\begin{array}{l}\text { Case series } \\
\quad(\mathrm{N}=20)\end{array}$ & $\begin{array}{l}\text { Heart }(\mathrm{n}=17) \\
\text { Heart/kidney } \\
\quad(\mathrm{n}=3)\end{array}$ & $\begin{array}{l}\mathrm{NAT}+\text { or } \\
\mathrm{HCV} \mathrm{Ab}+\end{array}$ & $\begin{array}{l}\text { Glecaprevir/pibrentasvir } \\
\text { Sofosbuvir/velpatasvir } \\
\text { Elbasvir/grazoprevir }\end{array}$ & $\begin{array}{l}\text { All patients on DAAs cleared } \\
\text { viremia, sustained } \\
\text { virologic response rate at } \\
12 \text { wk (SVR12) was } 90 \% \\
\text { based on } 10 \text { evaluable } \\
\text { patients }\end{array}$ \\
\hline $\begin{array}{l}\text { McLean and colleagues, }{ }^{17} \\
\text { UPenn, Philadelphia, Pa } \\
\text { (2019) }\end{array}$ & $\begin{array}{l}\text { Single arm } \\
\qquad(\mathrm{N}=10)\end{array}$ & Heart & $\begin{array}{l}\text { NAT }+ \text { or } \\
\text { HCV Ab+ }\end{array}$ & Elbasvir/grazoprevir & $\begin{array}{l}10 \text { patients, } 1 \text { death related to } \\
\text { antibody mediated } \\
\text { rejection with positive } \\
\text { cross-match } \\
90 \% \text { SVR } 12\end{array}$ \\
\hline $\begin{array}{l}\text { Wolfe and colleagues, } \\
\text { Duke, Durham, NC (2019) }\end{array}$ & $\begin{array}{l}\text { Safety protocol } \\
\qquad(\mathrm{N}=11)\end{array}$ & $\begin{array}{l}\text { Heart }(\mathrm{n}=8) \\
\text { Heart/lung } \\
\quad(\mathrm{n}=1) \\
\text { Lung }(\mathrm{n}=1) \\
\text { Lung/liver } \\
\quad(\mathrm{n}=1)\end{array}$ & $\begin{array}{l}\text { HCV NAT }+ \text { or } \\
\text { HBV NAT }+\end{array}$ & & $\begin{array}{l}\text { HCV therapy was initiated in } \\
6 \text {, and SVR } 12 \text { achieved in } 5 \\
\text { patient to-date } \\
100 \% \text { graft survival }\end{array}$ \\
\hline $\begin{array}{l}\text { Gidea and colleagues, }{ }^{19} \\
\text { NYU, New York, NY } \\
\text { (2019) }\end{array}$ & $\begin{array}{l}\text { Case series } \\
\quad(\mathrm{N}=12)\end{array}$ & Heart & NAT + genotype 1 & $\begin{array}{l}\text { Glecaprevir/ } \\
\quad \text { Pibrentasavir } \times 8 \mathrm{wk}\end{array}$ & $\begin{array}{l}\text { Early biopsy of heart } \\
\text { transplantation from donors } \\
\text { with active hepatitis C is } \\
\text { not associated with high } \\
\text { grade cellular or any } \\
\text { humoral rejection }\end{array}$ \\
\hline $\begin{array}{l}\text { Patel and colleagues, } \\
\text { Montefiore, New York, NY } \\
\text { (2018) }\end{array}$ & $\begin{array}{l}\text { Case series } \\
\qquad(\mathrm{N}=14)\end{array}$ & Heart & $\begin{array}{l}\text { Non-viremic } \\
(\mathrm{HCV} \mathrm{Ab+} \\
\text { and NAT- })\end{array}$ & None & $\begin{array}{l}\text { Over a median follow-up of } \\
256 \mathrm{~d}(192-377 \mathrm{~d}), 3 \\
\text { patients developed a } \\
\text { reactive } \mathrm{HCV} \mathrm{Ab} \text {, yet none } \\
\text { had detectable } \mathrm{HCV} \\
\text { viremia during prospective } \\
\text { monitoring }\end{array}$ \\
\hline $\begin{array}{l}\text { Schlendorf and colleagues, }{ }^{14} \\
\text { Vanderbilt, Nashville, Tenn } \\
\text { (2018) }\end{array}$ & $\begin{array}{l}\text { Case series } \\
\qquad(\mathrm{N}=13)\end{array}$ & Heart & $\begin{array}{l}\text { NAT }+ \text { or } \\
\text { HCV Ab+ }\end{array}$ & $\begin{array}{l}\text { Sofosbuvir/ledipasvir } \\
\text { Sofosbuvir/velpatasvir }\end{array}$ & $\begin{array}{l}1 \text { patient died during wk } 7 \text { of } \\
\text { treatment due to pulmonary } \\
\text { embolism. DAAs were well } \\
\text { tolerated in all treated } \\
\text { patients }\end{array}$ \\
\hline
\end{tabular}

$H C V$, Hepatitis C virus; $D A A$, direct-acting antiviral; $N A T$, nucleic acid amplification test; $S V R$, sustained virologic response; $A b$, antibody; $U C S D$, University of California San Diego; UPenn, University of Pennsylvania; HBV, hepatitis B virus; NYU, New York University; Montefiore, University Hospital for Albert Einstein College of Medicine, Montefiore Medical Center.

13 heart transplant recipients. Unlike the Donors of Hepatitis C Nucleic Acid Amplification Test-Positive Thoracic Allografts for Transplantation Evaluation in non-HCV Recipients study protocol, wherein DAA drugs were started immediately after transplant, recipients at Vanderbilt were started on delayed DAA therapy at a median of 33 days (IQR, 28-47 days), resulting in a significantly higher mean viral load at the initiation of therapy $(33,867,005 \pm 81,649,368 \mathrm{IU} / \mathrm{mL})$. Eight of 9 patients achieved SVR at 12 weeks; 1 patient died from a pulmonary embolus at 11 months, and 2 developed transient primary graft dysfunction. Updated results on this series that now includes 74 heart transplant recipients exposed to HCV (63 nucleic acid amplification test positive, $11 \mathrm{HCV}$ nucleic acid amplification test negative/antibody positive) at the recent International Society for Heart and Lung Transplantation annual scientific sessions (in Orlando, Fla, in April 2019) demonstrated 1-year survival of $90.2 \% .{ }^{15}$ Other 


\section{ACCEPTING HEPATITIS C INFECTED DONORS: EIGHT CONSIDERATIONS}

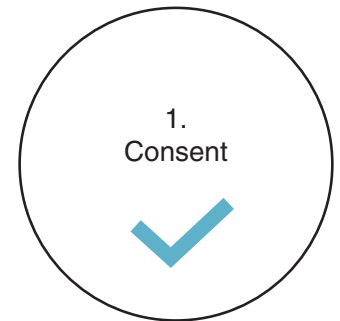

Multistep consent process disclosing unknown long-term outcomes

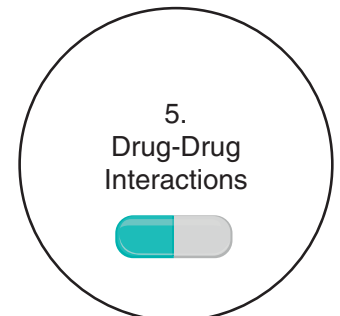

Monitoring of CNI levels, bradycardia with amiodarone

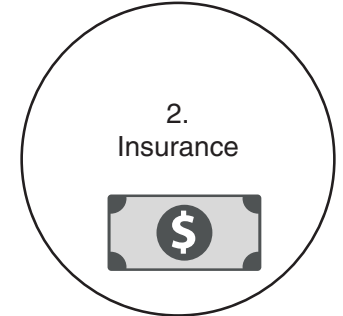

Each insurance payor may have strict criteria for use of a preferred DAA.

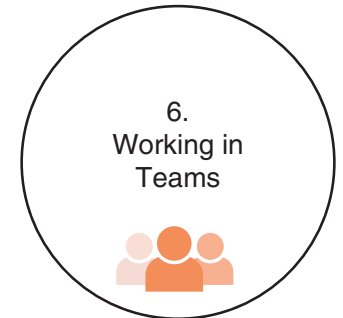

Hepatology, Infectious Diseases and Pharmacy involvement

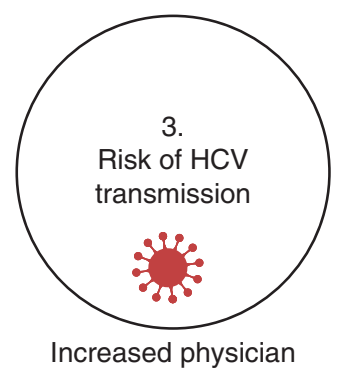

perioperative and patient post operative precautions

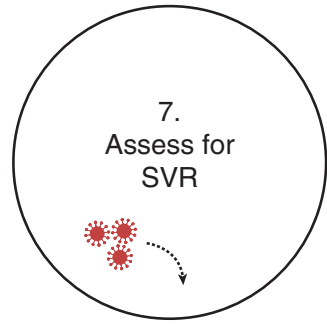

Patients may develop recurrence,

resistance or relapse (SVR: sustained virologic response)

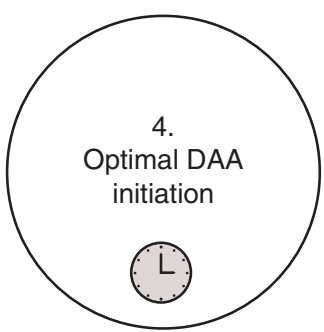

Ideally intraoperatively but challenging in real-world

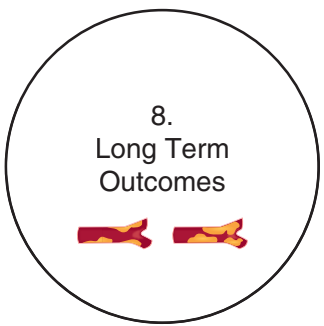

Consider increased monitoring for cardiac allograft vasculopathy

FIGURE 2. Important considerations in accepting hepatitis $\mathrm{C}$ virus-infected donor organs. DAA, Direct-acting antiviral; $H C V$, hepatitis $\mathrm{C}$ virus; $C N I$, calcineurin inhibitor; $S V R$, sustained virologic response.

contemporary studies from the heart transplant literature are included in Table 2. Recently, there have been several reports on positive outcomes in patients receiving combined organ transplants (eg, heart/kidney or lung/liver) from HCV-infected donors. ${ }^{16,18,21}$

\section{ACCEPTING HCV-INFECTED DONOR ORGANS: PROCEED WITH CAUTION}

There are several important considerations when using HCV-infected donor organs, as illustrated in Figure 2.

\section{Informed Consent}

Current protocols must include a comprehensive multistep consent process for the acceptance of HCV-infected donor organs, both at the time of listing and at the time of transplantation. ${ }^{22}$ In this consent process, it is important to communicate potential risks, including the uncertain long-term risks of acute and chronic rejection (eg, cardiac allograft vasculopathy and chronic lung allograft dysfunction) and recurrence of $\mathrm{HCV}$ in an immunosuppressed host. The consent process should include shared decision making between the clinical team and the patient.

\section{Insurance Coverage}

The cost of DAA therapy must be addressed; when there is uncertainty regarding payment for DAA therapy, the transplant center may need to guarantee coverage to prevent delay of treatment. Despite down-trending cost with market competition, DAA therapy can range from $\$ 26,400$ to $\$ 94,500$ for an 8 - to 12 -week course. ${ }^{21,23}$ Woolley and colleagues ${ }^{13}$ showed that recipients treated within hours of transplantation achieve SVR within 2 weeks, potentially allowing a shorter course of DAA therapy. There have been reported cases of HCV-related complications such as acute glomerulonephritis and cholestatic hepatitis related to delayed access to DAA therapy. $^{24,25}$ It is therefore critical for providers to obtain preapproval authorization or a contingency plan should insurance companies deny access to these drugs.

\section{Risk of HCV Transmission}

While patients are viremic, health care professionals should implement safe universal precautions such as using gloves for postoperative wounds and chest tubes, and safe disposal of needles. ${ }^{6}$

\section{Optimal Timing of DAA Initiation and Appropriate Length of Therapy}

The timing of DAA therapy initiation in the posttransplant setting remains controversial. Advantages to starting pre-emptive treatment include shorter treatment duration (and reduced cost) and avoidance of high-level viremia. However, early treatment may involve interruption of therapy due to renal dysfunction or inability to take medications by mouth. ${ }^{21}$ The benefits of delayed treatment include 


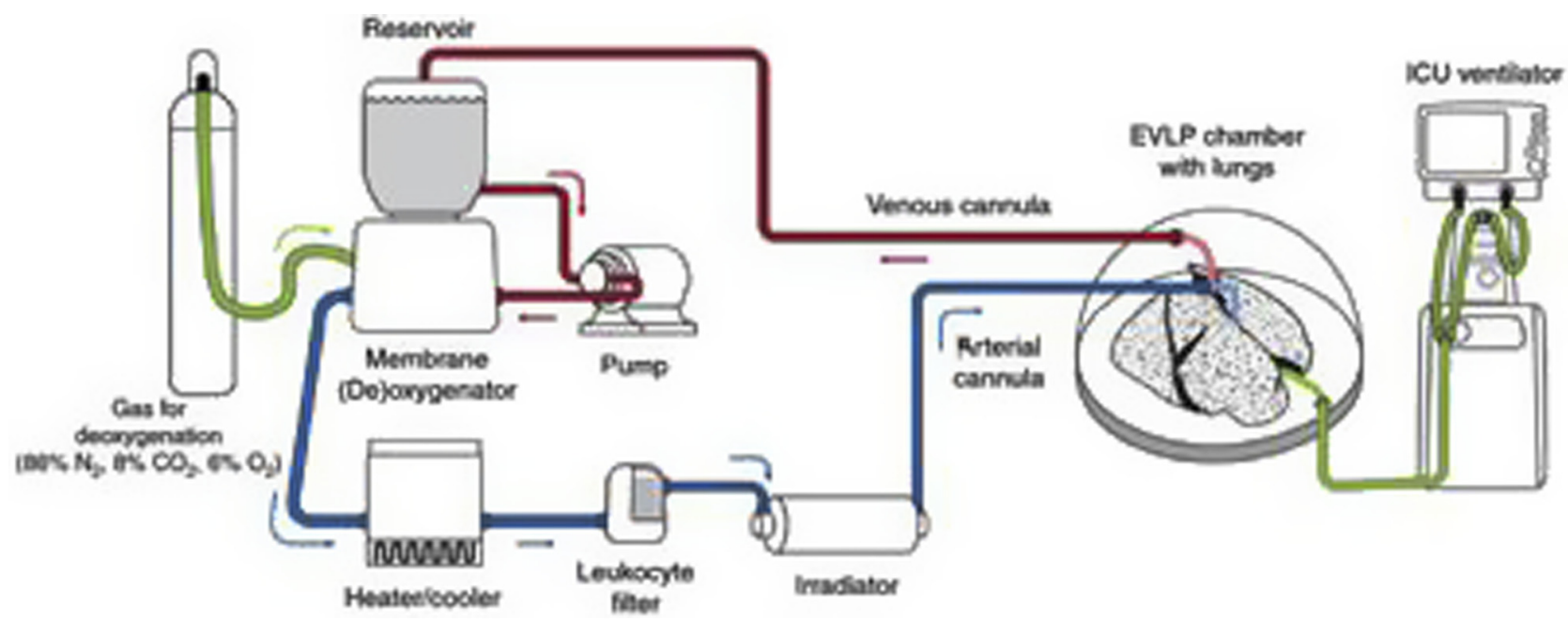

FIGURE 3. Customized illumination device and its use during ex-vivo lung perfusion, as described by Galasso and colleagues. ${ }^{28}$

avoidance of early drug interactions when immunosuppressive agents are not in steady state, time for stabilization of renal function, and the possibility that a small minority $(<10 \%$ of patients) may clear the virus spontaneously. Disadvantages of delayed treatment include potential complications of $\mathrm{HCV}$ viral replication, including acute hepatitis. Further studies are needed to determine the optimal initiation and duration of therapy.

\section{Drug-Drug Interactions}

Several clinically significant interactions between DAA and commonly used medications in the posttransplant period have been described, such as bradycardia resulting from the combination of DAAs and amiodarone. Table 1 describes some DAA interactions with calcineurin inhibitors. Recipients of HCV-infected organs will require regular and frequent monitoring of calcineurin inhibitor levels during the early posttransplant period. Among the Vanderbilt cohort, reported medication interactions included onethird of patients who required statin dose changes, twothirds required a change in either dose or type of antacid medication, and 2 required cessation of amiodarone. ${ }^{26}$

\section{Multidisciplinary Teams}

Input from pharmacy, infectious diseases, and hepatology colleagues will be instrumental in the management of immunocompromised patients with acute $\mathrm{HCV}$ infection.

\section{Therapy Failure}

Treatment-emergent resistance-associated substitutions in $\mathrm{HCV}$ can result in treatment failure. The rate of failure in patients without cirrhosis is $<5 \%$. The American Association for the Study of Liver Disease practice guidelines provide an informative approach to patients who do not respond to therapy.

\section{Long-Term Safety}

Given that HCV infection has immunologic consequences, it is plausible that $\mathrm{HCV}$ transmission may augment risk of both acute rejection and cardiac allograft vasculopathy or chronic lung allograft dysfunction. Current studies do not show increased risk of treated acute cellular rejection; however, longer follow-up time is required to determine whether there is any association with antibodymediated rejection and development of donor-specific antibodies. The short-term risk of cardiac allograft vasculopathy was evaluated among 14 heart transplant patients serially monitored at Vanderbilt with 6-month $(\mathrm{n}=20)$ and 1-year $(\mathrm{n}=16)$ intravascular ultrasound testing; median maximal intimal thickness was $0.39 \mathrm{~mm}$ (IQR, 0.25$0.80 \mathrm{~mm})$ and $0.65 \mathrm{~mm}(\mathrm{IQR}, 0.37-0.98 \mathrm{~mm})$, respectively, with an absolute median increase of $0.15 \mathrm{~mm}$ (IQR, -0.03 to $0.42 \mathrm{~mm})^{27}$

On the horizon are strategies to inactivate HCV before transplantation to prevent viral transmission altogether. Light-based therapies (LbT) used during normothermic ex vivo lung perfusion (EVLP) is a novel approach to reduce $\mathrm{HCV}$ viral load to prevent donor-derived transmission. Galasso and colleagues ${ }^{28}$ developed an illumination device to deliver ultraviolet $\mathrm{C}$ irradiation and photodynamic therapy to 9 discarded HCV-infected lungs on EVLP. With this technology, viral load in both tissue and perfusate were significantly reduced. The authors suggest that, as a model, EVLP + LbT could be applied to other viruses (eg, hepatitis $\mathrm{B}$ virus and human immunodeficiency virus) and to other donor organs such as heart and kidney (Figure 3).

More recently, this same group presented results of the first clinical trial evaluating EVLP $+\mathrm{LbT}^{28}$ The study included 20 patients who received NAT $+\mathrm{HCV}$ donor lungs (11 received EVLP alone vs 9 EVLP + LbT). Patients who became viremic were started on sofosbuvir/velpatasavir for 12 weeks. Waitlist time was significantly shorter for 
patients who received HCV+ organs 17 days (1-312 days) versus 42 days (1-1102 days) and there was no reduction in posttransplant survival. In the subgroup of EVLP versus EVLP/UVC for HCV-infected donors, median viral load was significantly lower at day $7,82 \%$ of those with EVLP/UVC had transmission of HCV (compared with $100 \%$ with EVLP), and no recipients had recurrence of HCV viremia after DAA therapy. ${ }^{29}$

\section{CONCLUSIONS}

The use of HCV-infected organs appears to be a safe strategy that can significantly and rapidly expand the donor pool. This strategy is associated with reduced wait times for donor organs, and therefore reduced morbidity and mortality for potential candidates on the waitlist. The use of DAAs in this setting therefore appears to be cost-neutral, the drugs are well tolerated, and modification to current induction and maintenance immunosuppression protocols are not required. The transplant community continues to tread lightly while we await future studies that address the remaining uncertainties of this innovative strategy, such as timing and duration of DAA therapy and the results of donor $\mathrm{HCV}$ infection on long-term transplant outcomes.

\section{Conflict of Interest Statement}

Authors have nothing to disclose with regard to commercial support.

\section{References}

1. The International Society for Heart \& Lung Transplantation. International Thoracic Organ Transplant (TTX) Registry data slides. Available at: https:// ishltregistries.org/registries/slides.asp. Accessed April 30, 2019.

2. UNOS Data and Transplant Statistics. Organ donation data. Available at: https:// unos.org/data/. Accessed April 22, 2019.

3. Durand CM, Bowring MG, Thomas AG, Kucirka LM, Massie AB, Cameron A, et al. The drug overdose epidemic and deceased-donor transplantation in the United States: a national registry study. Ann Intern Med. 2018;168:702-11.

4. Centers for Disease Control and Prevention. Increase in hepatitis $\mathrm{C}$ infections linked to worsening opioid epidemic. Available at: https://www.cdc.gov/ nchhstp/newsroom/2017/hepatitis-c-and-opioid-injection-press-release.html. Accessed April 30, 2019.

5. Feld JJ, Kowdley KV, Coakley E, Sigal S, Nelson DR, Crawford D, et al. Treatment of HCV with ABT-450/rombitasvir and dasabuvir with ribavirin. $N$ Engl J Med. 2014;370:1594-603.

6. Moayedi Y, Fan CPS, Gulamhusein AF, Manlhiot C, Ross HJ, Teuteberg JJ, et al. Current use of hearts from hepatitis $\mathrm{C}$ viremic donors: a United Network for Organ Sharing registry analysis. Circ Heart Fail. 2018;11:e005276.

7. Mehra MR, Jarcho JA, Cherikh W, Vaduganathan M, Lehman RR, Smits J, et al. The drug-intoxication epidemic and solid-organ transplantation. N Engl J Med. 2018;378:1943-5.

8. Chung RT, Ghany MG, Kim AY, Marks KM, Naggie S, Vargas HE, et al. Hepatitis C guidance 2018 update: AASLD-IDSA recommendations for testing, managing, and treating hepatitis C virus infection. Clin Infect Dis. 2018;67:1477-92.

9. Spengler U. Direct antiviral agents (DAAs). A new age in the treatment of hepatitis C virus infection. Pharmacol Ther. 2018;183:118-26.

10. Charlton M, Everson GT, Flamm SL, Kumar P, Landis C, Brown RS Jr, et al. Ledipasvir and sofosbuvir plus ribavirin for treatment of $\mathrm{HCV}$ infection in patients with advanced liver disease. Gastroenterology. 2015;149:649-59.

11. Colombo M, Aghemo A, Liu H, Zhang J, Dvory-Sobol H, Hyland R, et al. Treatment with ledipasvir-sofosbuvir for 12 or 24 weeks in kidney transplant recipients with chronic hepatitis C virus genotype 1 or 4 infection. Ann Intern Med. 2017; 166:109.

12. Liu C-H, Chen Y-S, Wang S-S, Liu C-J, Su T-H, Yang H-C, et al. Sofosbuvirbased interferon-free direct acting antiviral regimens for heart transplant recipients with chronic hepatitis C virus infection. Clin Infect Dis. 2018;66: 289-92.

13. Woolley AE, Singh SK, Goldberg HJ, Mallidi HR, Givertz MM, Mehra MR, et al. Heart and lung transplants from $\mathrm{HCV}$-infected donors to uninfected recipients. $N$ Engl J Med. 2019;380:1606-17.

14. Schlendorf KH, Zalawadiya S, Shah AS, Wigger M, Chung CY, Smith S, et al. Early outcomes using hepatitis C-positive donors for cardiac transplantation in the era of effective direct-acting anti-viral therapies. J Heart Lung Transplant. 2018;37:763-9.

15. Schlendorf K, Zalawadiya S, Shah A, Wigger M, Perri R, Danter M, et al. Successful transplantation of 74 hepatitis C-exposed donor hearts in the era of direct-acting antiviral therapies. Presented at: ISHLT 39th Annual Meeting and Scientific Sessions; April 3-6, 2019; Orlando, FL.

16. Aslam S, Yumul I, Mariski M, Pretorius V, Adler E. Outcomes of heart and heartkidney transplantation from hepatitis $\mathrm{C}$ virus (HCV) positive donors into $\mathrm{HCV}$ negative recipients. J Heart Lung Transplant. 2019;38:S66-7.

17. McLean RC, Reese PP, Acker M, Atluri P, Bermudez C, Goldberg LR, et al. Transplanting hepatitis C virus-infected hearts into uninfected recipients: a single-arm trial. Am J Transplant. 2019;19:2533-42.

18. Wolfe CR, Sen S, Kappus MR, Schroder JN, Daneshmand MA, Haney JC, et al. Hepatitis and thoracic transplantation - no more virus non-grata. J Heart Lung Transplant. 2019;38:S308.

19. Gidea CG, Narula N, Reyentovich A, Smith D, Pavone J, Katz S, et al. The impact of $\mathrm{HCV}$ viremia in heart transplant recipients from donors with $\mathrm{HCV}$ infection on acute and humoral cellular rejection. J Heart Lung Transplant. 2019;38:S66.

20. Patel SR, Madan S, Saeed O, Sims DB, Shin JJ, Nucci C, et al. Cardiac transplantation from non-viremic hepatitis C donors. J Heart Lung Transplant. 2018;37: 1254-60.

21. Wettersten N, Tran H, Mekeel K, Pretorius V, Adler E, Aslam S. Successful heart-kidney transplantation from a Hepatitis C viremic donor to negative recipient: one year of follow-up. Transpl Infect Dis. 2019;21:e13002.

22. Moayedi Y, Gulamhusein AF, Ross HJ, Teuteberg JJ, Khush KK. Accepting hepatitis C virus-infected donor hearts for transplantation: multistep consent, unrealized opportunity, and the Stanford experience. Clin Transplant. 2018;32: e13308.

23. Abutaleb A, Kottilil S, Wilson E. Glecaprevir/pibrentasvir expands reach while reducing cost and duration of hepatitis C virus therapy. Hepatol Int. 2018;12: 214-22.

24. Wadei HM, Pungpapong S, Cortese C, Alexander MP, Keaveny AP, Yang L, et al. Transplantation of HCV-infected organs into uninfected recipients: advance with caution. Am J Transplant. 2019;19:960-1.

25. Kwong AJ, Wall A, Melcher M, Wang U, Ahmed A, Subramanian A, et al. Liver transplantation for hepatitis $\mathrm{C}$ virus (HCV) non-viremic recipients with $\mathrm{HCV}$ viremic donors. Am J Transplant. 2019;19:1380-7.

26. Boyle K, Fowler RE, Pollack A, Edmonds C, Gray J, Lindenfeld J, et al. Appropriate management of drug interactions results in safe use of hepatitis C therapies in heart transplant recipients. J Heart Lung Transplant. 2019;38: S200-1.

27. Zalawadiya S, Lindenfeld J, Haddad E, Shah A, Wigger M, Negrotto S, et al. Intracoronary intimal thickness in transplant recipients of hepatitis C-positive donor hearts. J Heart Lung Transplant. 2019;38:S281.

28. Galasso M, Feld JJ, Watanabe Y, Pipkin M, Summers C, Ali A, et al. Inactivating hepatitis $\mathrm{C}$ virus in donor lungs using light therapies during normothermic ex vivo lung perfusion. Nat Commun. 2019;10:481.

29. Cypel M, Galasso M, Ribeiro R, Wilson B, Bagnato V, Kurachi C, et al. A clinical trial evaluating the effects of ultra-violet $\mathrm{C}$ treatment (UVC) during ex vivo lung perfusion (EVLP) as a method of inactivating hepatitis $\mathrm{C}$ infection in donor lungs. J Heart Lung Transplant. 2019;38:S53-4. 